A. EUR exon

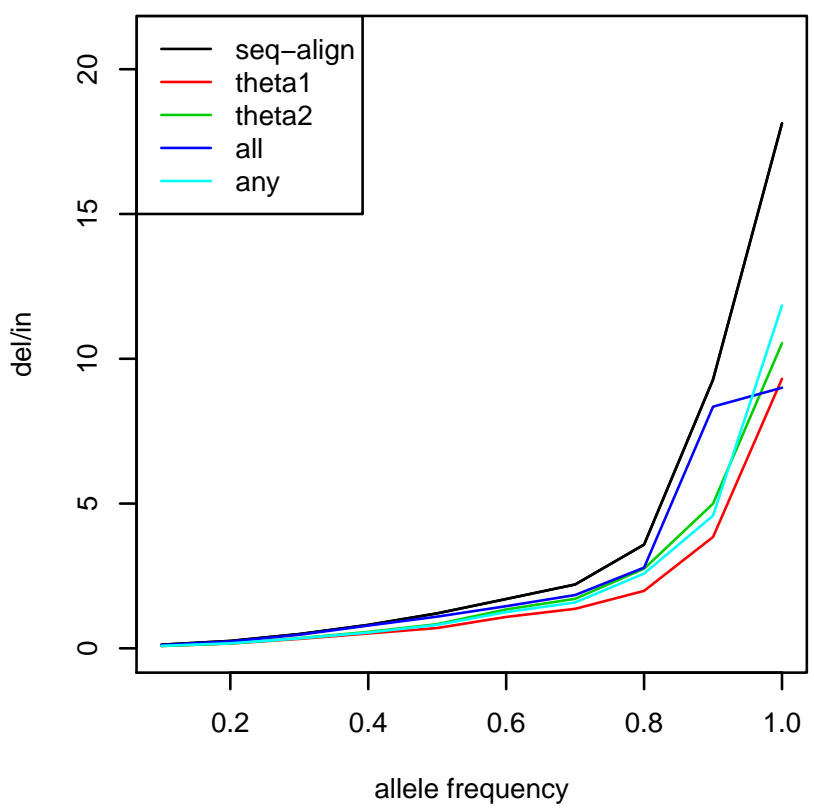

\section{EUR trratio}

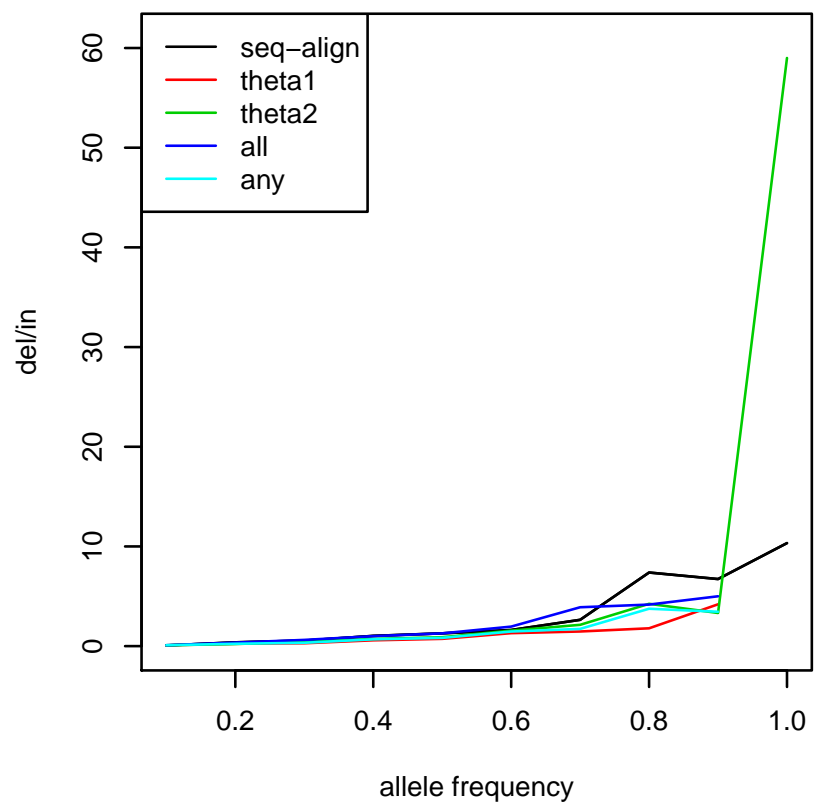

\section{B. EUR gene}

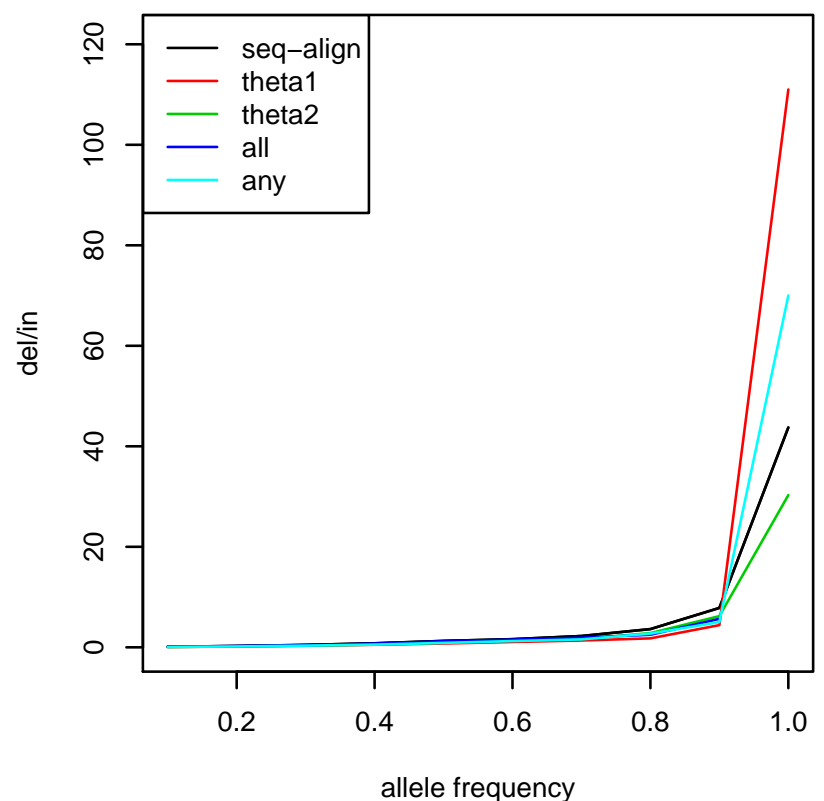

E. EUR total

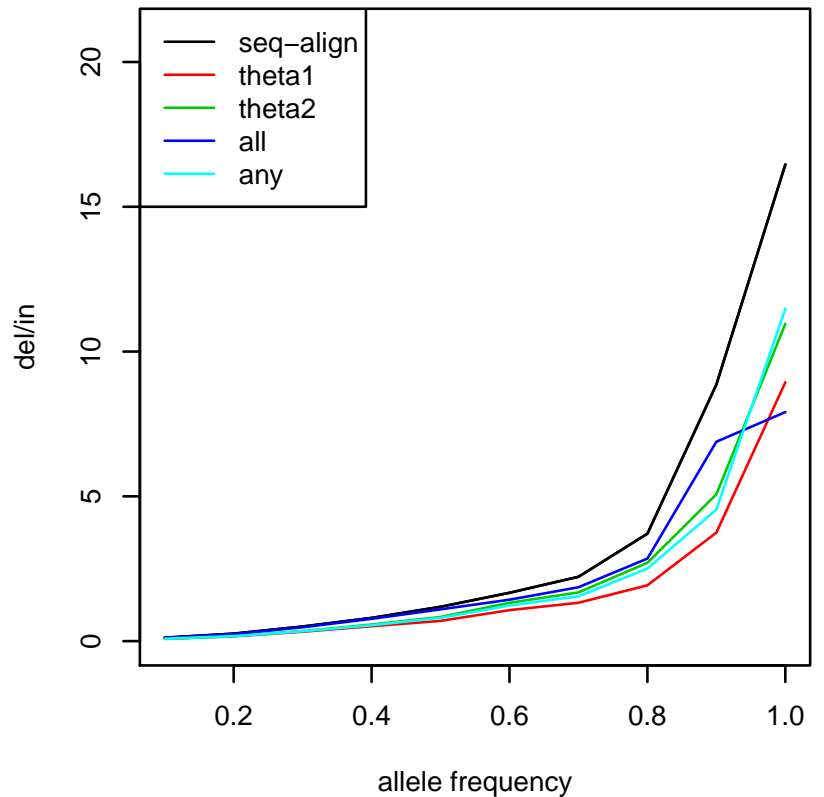

C. EUR repeats

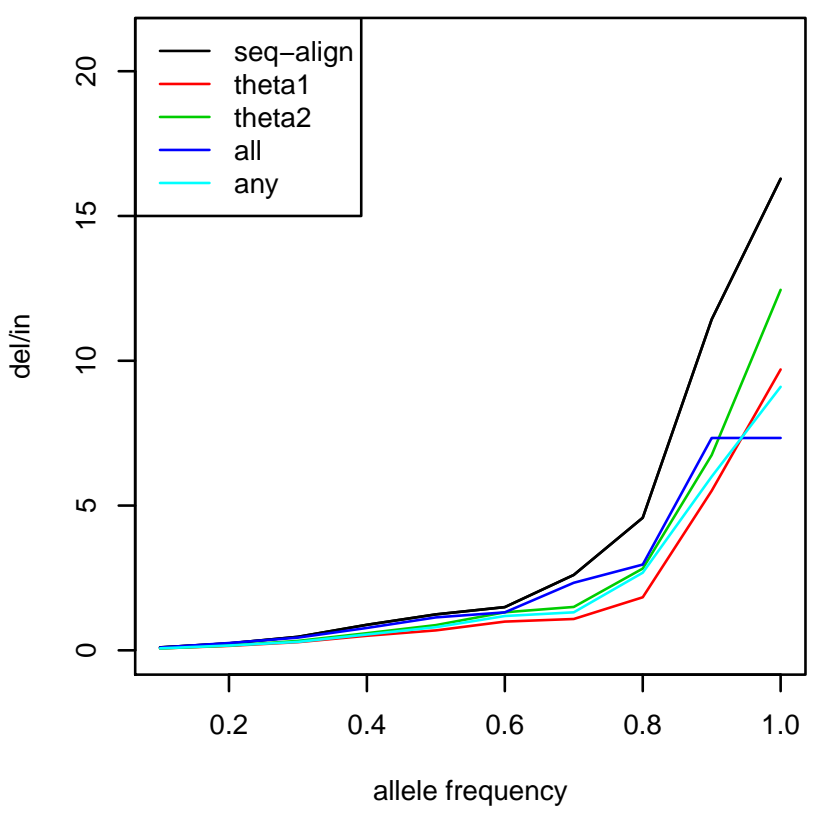

F. YRI total

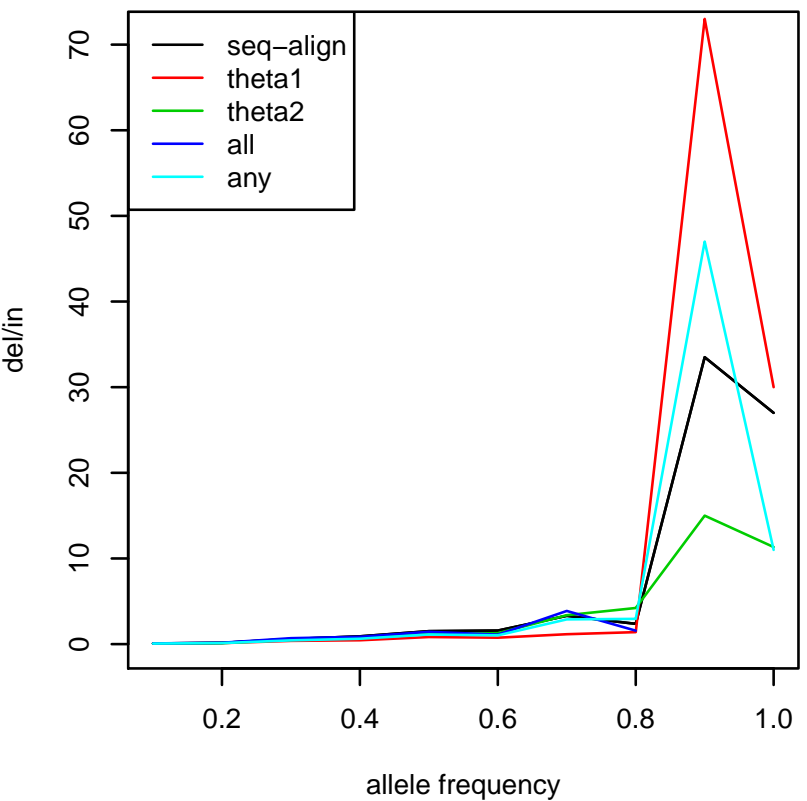

